\title{
Türkiye'de Freelance Gazetecilerin Perspektifinden Freelance Gazetecilik: Profesyonel Kimlik, (Dez)avantajlar ve Sorunlar
}

\author{
İlker Erdoğan \\ doçent doktor, izmir kâtip çelebi üniversitesi \\ sosyal ve beşeri bilimler fakültesi \\ medya ve iletişim bölümü \\ ilkgazeteci@gmail.com \\ Orcid: 0000-0002-6690-4681
}

\begin{abstract}
Freelance Journalism from the Perspective of Freelance Journalists in Turkey: Professional Identity, (Dis)advantages and Issues

Based on semi-structured interviews, this study is concerned with freelance journalists often neglected or marginalized in journalism research. This study is a step toward filling a gap in research field about freelance journalists who leave their traditional employer-oriented journalist professions for self-employment in Turkey. In the study, the database of the Journalists Union of Turkey and the snowball sampling method starting from a network of friends are used for analyzing the subject. Based upon three main research problematique, there are seventeen interviews conducted with freelance journalists: (1) The professional identity of freelance journalists in Turkey, (2) the advantages and disadvantages of working as a freelance journalist in Turkey, (3) the fundamental problems in the field of freelance journalism in Turkey. It is concluded as follows: Primarily, the government should attempt for protecting freelance journalists' work rights, eliminating the risk of deprivation of employment and revenue assurance, and improving the working conditions.
\end{abstract}

keywords: freelance journalism, freelance journalists, indepth interview, news industry, news production, Turkey 


\section{Résumé}

\section{Le journalisme freelance du point de vue des journalistes indépendants en Turquie: identité professionnelle, (dés)avantages et problèmes}

Cette étude qui se base sur des entretiens semi-structurés faits avec des journalistes indépendants. Les journalistes indépendants sont souvent négligés et marginalisés dans les recherches journalistiques. Cette étude constitue un pas en avant pour combler une lacune dans le domaine de la recherche concernant les journalistes indépendants en Turquie, qui quittent les emplois traditionnels pour le travail indépendant. Dans cette étude, le chercheur a non seulement profité de la base de données du syndicat des journalistes de Turquie mais aussi il a établi des liens personnels avec sone cercle d'amis. Des entretiens ont été menés avec dix-sept journalistes indépendants autour de trois thèmes de recherche principales: (1) L'identité professionnelle des journalistes indépendants en Turquie, (2) les avantages et les inconvénients de travailler en tant que journaliste indépendant en Turquie, (3) les problèmes fondamentaux dans le domaine du journalisme indépendant en Turquie. II a été conclu qu'il faut en priorité que le gouvernement intervienne pour la protection des droits professionnels des journalistes indépendants, $r$ la suppression du risque de perte du travail, la garantie de revenu et l'amélioration des conditions de travail.

mots-clés: le journalisme indépendant, les journalistes indépendants, l'interview approfondie, l'industrie de l'actualité, la production de l'actualité, la Turquie 


\section{Öz}

Yarı yapılandırılmış görüşmelere dayanan bu çalışma, gazetecilik araştırmalarında sıklıkla ihmal edilen ya da marjinalleştirilen freelance gazetecilerle ilgilidir. Bu çalışma, Türkiye'de, kendi hesabına çalışmak için geleneksel işveren odaklı gazetecilik mesleğinden ayrılan freelance gazeteciler hakkında araştırma alanındaki boşluğun doldurulmasına yönelik bir adımdır. Çalışmada, görüşmelere katılacak gazetecilere ulaşmak için araştırmacı hem Türkiye Gazeteciler Sendikası (TGS) veri tabanından faydalanmış hem de arkadaş çevresi ile kişisel bağlantılar kurmuştur. Üç ana araştırma teması dikkate alınarak on yedi freelance gazeteci ile görüşmeler gerçekleştirilmiştir: (1) Türkiye'de freelance gazetecilerin profesyonel kimliği, (2) Türkiye'de freelance gazeteci olarak çalışmanın avantajları ve dezavantajları, (3) Türkiye'de freelance gazetecilik alanındaki temel sorunlar. Freelance gazetecilerin mesleki haklarının korunması, iş ve gelir güvencesinden yoksun kalma riskinin ortadan kaldırılması ve çalışma koşullarının iyileştirilmesi için öncelikle devletin girişimde bulunması ve freelance gazetecilik yapan gazetecilere yardımcı olması gerektiği sonucuna varılmıştır.

anahtar kelimeler: freelance gazetecilik, freelance gazeteciler, derinlemesine görüşme, haber endüstrisi, haber üretimi, Türkiye 


\section{Giriș}

Haber endüstrilerinde giderek artan belirsizlik, istikrarsızlık ve bütçe kesintileri (McChesney ve Nichols, 2010; McChesney ve Pickard, 2011), haber kuruIuşlarını daha az sermayeyle üretim yapmaya zorlamakta (Kaye ve Quinn, 2010) ve bu nedenle hem gazetecilik meslek pratiklerinde hem de haber üretim süreçlerinde hızlı bir değişim ve dönüşüm yaşanmaktadır. Bu sürece ayak uydurmaya çalışan haber kuruluşları, yeni iş modellerine odaklanmakta ve sürekli değişen iş ortamındaki yenilikler, haber kuruluşlarında üretim yeterliliği için yeni taleplerin ortaya çıkmasına neden olmaktadır (Andersson ve Wiik, 2013, s. 706). Ayrıca, haber endüstrilerindeki ekonomik krizler, gazetecilerin iş bulma şansını azaltmakta ve sonuç olarak, endüstride freelance (serbest) olarak adlandırılan alışılmamış (atypical) haber emekçilerinin sayısı bütün dünyada artmaktadır. Geleneksel ya da özellikle küçük çaplı ve bağımsız online yayın yapan haber kuruluşlarında, girişimcilik ruhuna sahip ve markalaşmış freelance gazeteciler, yaşamsal bir önem kazanmaktadır. Gazeteler, azalan kaynaklarla (sermayeyle) üretim yapmaya devam ederken, içerik üretimindeki boşlukları doldurmak için kısmen ya da tamamen freelance gazetecilere yönelmekte ve freelance gazetecilere duyulan güven giderek artmaktadır.

Yazılı ve elektronik medya kuruluşlarına, internet haber sitelerine ya da enformasyon sektörüne haber materyali temin eden, haber endüstrilerinde, serbest gazetecilik mesleğini icra eden, kendi hesabına çalışan ve bağımsız olan freelance gazeteciler, nadiren akademik araştırmaların odağında yer almaktadır. Gazetecilik araştırmaları, haber emekçileri ile ilgili bir kategori olarak kabul edilen freelance gazetecileri dikkate almama eğilimi göstermektedir. Gazeteci profilleri ve gazetecilerin mesleki kariyerleri ile ilgili araştırmaların büyük bir çoğunluğu, bir editöryal kadro içinde çalışmak için işe alınan gazeteciler arasında gerçekleştirilen büyük ölçekli anketlerden oluşmaktadır. Bu araştırmalarda, geçici olarak çalışan, farklı yeteneklere sahip freelance gazeteciler yerine ağırlıklı olarak ayrıcalık tanınmış ve tamgün çalışan haber emekçilerinin profesyonel kültürleri kayda geçirilmektedir (Wahl-Jorgensen ve Hanitzsch, 2009, s. 12). Freelance ya da girişimci gazeteciler, bu çalışmalarda, genellikle inmal edilmekte ya da marjinal hale getirilmektedir (Ryan 2009, s. 648; Edström ve Ladendorf, 2012, s. 711). Yine aynı şekilde, bir meslek olarak gazetecilikle ilgili sorunsallara odaklanan pek çok bilim insanının, söz konusu sorunsalları ele aldıkları çalışmalarına freelance gazeteciliği dâhil etmediği görülmektedir (Das, 2007, s. 142). Ancak, freelance gazetecilerin çalışma koşullarını araştırmanın, modern gazeteciliğin önemli yönlerini anlamak için yararlı olacağı da düşünülmektedir (Gollmitzer, 2014, s. 826). Alanyazında, freelance gazetecilerin odak noktasında yer aldığı araştırmaların görece az sayıda olduğu görülmekte ve ayrıca, niteliksel araştırma yaklaşımı ile gerçekleştirilen araştırmalara daha az rastlanmaktadır. Türkiye'de ise, alanyazında, freelance gazetecileri, araştırma nesnesi olarak ele alan herhangi bir akademik makale bulunmamaktadır.

Bu çalışmanın amacı, Türkiye'de profesyonel freelance gazetecilerin meslek yaşamını ve yaşadıkları sorunları açıklığa kavuşturmaktır. Türkiye'de gazete- 
cilik faaliyeti yürüten freelance gazetecilerin hem kendilerini hem de gazeteciliği algılama, anlamlandırma biçimlerini inceleyen ve tartışan bu çalışma, şu üç ana tema kapsamında toplanabilecek derinlemesine görüşme sorularına verilen yanıtları bir araya getirmiştir. Bu temalar, Türkiye'de freelance gazetecilerin profesyonel kimliği; Türkiye'de bir freelance gazeteci olarak çalışmanın avantajları ve dezavantajları; Türkiye' de freelance gazetecilik alanındaki temel sorunlar şeklinde sıralanabilir. Derinlemesine görüşme sorularına verilen yanıtları değerlendirmeden önce, freelance gazeteciliğe ve gazetecilere ilişkin genel bir kavramsal/kuramsal alanyazın taraması yapılmış, daha önce diğer ülkelerde gerçekleştirilen araştırmaların bulgularına yer verilmiş ve son olarak, bu çalışmanın metodolojik yaklaşımının genel çerçevesi çizilmiş, bulgular sunulmuş ve tartışılmıştır.

Bu çalışmada, derinlemesine yarı yapılandırılmış görüşme yöntem ve tekniği uygulanarak on yedi freelance gazeteciyle görüşmeler yapılmıştır. Türkiye'de freelance gazetecilik alanında çalışan gazetecilerden oluşan bir örneklem oluşturabilmek için araştırmacı hem Türkiye Gazeteciler Sendikası'nın (TGS) veri tabanından faydalanmış hem de arkadaş çevresi ile kişisel bağlantılar kurmuştur. Araştırmaya katılan freelance gazetecilerin bazıları Uluslararası Basın Kartı'na sahiptir. Gazetecilerin büyük bir kısmı birkaç özel işverenden iş almaktadır. Sadece bir tek işveren için çalışan gazeteciler ise istisnadır. Gazetecilik işçilerinin ya da emekçilerinin bu kategorisi, yani, freelance gazeteciler hakkında daha fazla şey öğrenmek için gerçekleştirilen görüşmelerde, genel olarak freelance gazeteciliğin sorunları tespit edilirken, freelance gazetecilerin önerileri ya da tavsiyeleri de ortaya konulmuştur. Bu sorunlar, genel olarak, Türkiye'de, profesyonel freelance gazetecilerin çalışma koşullarından kaynaklanan mesleki tatmin ya da tatminsizlik duygusu ile ilişkilendirilmiştir.

\section{Freelance Gazetecilik}

Freelance gazetecilik, kendi hesabına çalışan, serbest ve bağımsız gazetecilerin mesleki faaliyet alanıdır. Bu gazeteciler, ürün ve hizmetlerinin (haber vb.) telif ya da bir başka ifadeyle, fikir ve mülkiyet hakkını ellerinde tutmaktadır. Hem söz konusu ürün ve hizmetleri çoğaltma ve dağıtma hem de ürün ve hizmetler üzerinde editöryal kontrol hakkına sahip olan bu gazeteciler, bu haklarını belirli bir ücret karşılığında işverene devretmektedir. Herhangi bir haber kuruluşunun yerleşik haber merkezinde olduğundan görece çok daha fazla bağımsız ve özgür olan freelance gazeteciler, haber endüstrisinde faaliyet gösterdikleri kendilerine ait bir yaşam alanına sahiptir (Smith, 2011, s. 61). Bir başka anlatımla, freelance gazetecilik, freelance (serbest) gazetecilerin, uzun vadeli olarak belirli bir işverene bağlı olmaksızın, kendi hesaplarına, bağımsız çalıştıkları bir gazetecilik türüdür. Ayrıca, freelance gazetecilik (Mathisen, 2017; Cohen, 2016; Hunter, 2015), topluluk sermayesine dayalı gazeteciliğin-crowdfunded journalism (Jian ve Shin, 2015; Jian ve Usher, 2014) ya da girişimci gazeteciliğin-entrepreneurial journalism (Porlezza ve Splendore, 2016) bir parçası ya da aşaması olarak kabul edilmektedir. 
Geleneksel haber kuruluşları, bütçe kesintileri ve kapanma tehlikesiyle boğuşurken, gazeteciliği finanse etmek için uygulanabilir bir yöntem olarak gündeme gelen topluluk sermayesi yaratma (crowdfunding) fikri büyük bir mesafe kazanmıştır (Aitamurto, 2011, 2015; Hunter, 2015; Jian ve Usher, 2014; Carvajal vd., 2012). Jian ve Usher (2014, s. 155), küçük miktarların bir araya gelerek bir sermaye yaratması süreci olan topluluk sermayesine dayalı gazeteciliği (crowdfunded journalism) "gazetecilerin, haberlerini finanse etmek için sıradan insanlardan (halktan) gelen mikro ödemelere bel bağladığı alışılmamış bir iş modeli" olarak tanımlamaktadır. Kaynakların (sermayenin) kıt olduğu bir finansal ortamda, topluluk sermayesi yaratma, freelance gazetecilerin kendi işlerini desteklemenin bir yolu olarak görülmekte ve övgü almaktadır (Carvajal vd., 2012). Girişimci gazetecilik (entrepreneurial journalism) ise Cohen'in (2015b) de belirttiği gibi, haber endüstrisindeki ve gazetecilik pratiğindeki mevcut krizin tam ortasında, bir çözüm olarak sunulmaktadır. Girişimci gazeteciliğin pratiklerine ilişkin genel geçer kuralların varlığı belirsizliğini korurken, bu gazetecilik türü, adapte olmayı, esnekliği ve kendine güvenmeyi öğrenen, kendi markasını yaratarak ve kendi hesabına çalışarak kariyerini güçlendiren girişimci gazeteci nosyonunu yüceltmektedir. Bütün bunların ötesinde, freelance gazetecilik, gazetecilik mesleğindeki dönüşümlerin bir sonucu ve gazetecilik üretim maliyetlerini düşürmek için geleneksel gazetecilik üretimine alternatif bir gazetecilik pratiği olarak ortaya çıkmış olan bir dış kaynak kullanımıdır-outsourcing (Cohen, 2015a, s. 103-104).

Freelance gazetecilik ile ilgili bir başka yaklaşıma göre de freelance gazetecilik, yurttaş gazeteciliği ile aynı şey değildir. Çünkü freelance gazeteciler, gazeteciliğin bir ticaret olduğunu varsaymakla birlikte, profesyonel sorumluluklar üstlenirler, ancak, haber endüstrisinin otoritesini kabul etmezler (Smith, 2011, s. 61). Gynnild'e (2005: 112) göre, freelance gazeteciliği, haber endüstrisi için cazip hale getiren asıl unsur, gazetecilik idealleri değil, ekonomik ideallerdir, çünkü endüstri mali sonuçlarla ilgilenmektedir. Bu noktada, bu gazetecilik türü, gazetecilere esneklik sağladığı, işletmenin lehine olduğu ve bir ürün olarak habere çok fazla değer verdiği için takdir edilmektedir. Haber emekçilerinin harcadığı zamanı ve görev önceliklerini belirleyen işletmelerin, gazeteciler üzerindeki kontrol gücünü artırmakta ve işverene daha az sorumluluk yüklemektedir. Ayrıca, freelance ücretler nedeniyle, freelance gazeteciler ve freelance olmayan gazeteciler arasındaki rekabet artmaktadır. Freelance gazetecilik söz konusu olduğunda ön plana çıkan kavramlardan biri yukarıda belirtildiği gibi esnekliktir. Das'a (2007, s. 156) göre, bir freelance gazeteci olarak mesleğe devam etme tercihinde bulunmanın en önemli nedeni, çalışma saatlerindeki, yaşam biçimi tercihlerindeki ve iş tercih etme yeteneğindeki esnekliktir. Örneğin, İsveçli gazetecilerle yaptığı görüşmelerde, Edström ve Ladendorf (2012, s. 718), freelance gazetecilerin, daha uzun tatiller ve ailelerinin intiyaçlarına karşılık verebilme, çocuklarının bakımı gibi örnekler vererek yaşamlarındaki esnekliği vurguladıklarını ve aynı zamanda, devamlı pozisyonlarda çalışan gazetecilere kıyasla hayatlarından çok daha fazla memnun olduklarını görmüştür. 
Bunlara ek olarak, freelance gazeteciliğin başka avantajları ve dezavantajları bulunmaktadır (Gynnild, 2005). Bu gazetecilik türü, özellikle iki konuda avantajıdır. Birincisi, freelance gazeteciler, kişisel tercihleri doğrultusunda herhangi bir işveren ya da aynı anda birkaç işveren için iş yapma özgürlüğüne sahiptir. Yani, kurumsal sadakat, gazetecinin inisiyatifindedir. Çünkü freelance gazeteciler için bir işverene sadakat çok riskli olabilmektedir. İkincisi, birden fazla aktörün yer aldığı bir endüstride, freelance gazeteciler, kişisel bir marka sahibi olmanın başarıı olmak için bir zorunluluk olduğunu bilmektedir. Kişisel bir marka sahibi olma noktasında, güvenilirlik ve ürün (haber) kalitesi kanıksanmaktadır. Bütün bunların yanı sıra, bu gazetecilik türü, özellikle iş ve gelir söz konusu olduğunda dezavantajıdır. Freelance gazeteciler, iş ve gelir güvencesinden yoksun olarak yaşamayı göze almak ya da almamak noktasında bir karar vermek zorundadır, çünkü sabit bir gelir kaynağı ya da varsayılan gelir olasııkları arasında bir ikilem yaşanmaktadır. Freelance gazetecilik yapma kararı alan bir gazeteci, kişisel gazetecilik kariyeri için bir tercihte bulunur. Gazeteci ya yüksek bir gelir elde edecektir ya da iş ve gelir güvencesinden yoksun kalacaktır. Öyle ki, modern iş yaşamında, zarara uğrama ve para kazanma ekseninde, freelance gazeteciler oldukça büyük bir risk almaktadır.

\section{Freelance Gazeteciler}

Geleneksel medya kuruluşlarının yerleşik haber merkezleri dışında gazetecilik faaliyetleri yürüten gazeteciler; serbest çalışanlar ya da serbest meslek sahipleri (freelancers), geçici işçiler (temporary workers) ya da alışılmamış işçiler (atypical workers) gibi farklı isimlerle adlandırımaktadır (Mathisen, 2017, s. 910). Uluslararası Gazeteciler Federasyonu'na (Walters vd., 2006, s. 6) göre, alışımamış işçiler terimi, sürekli ya da tamgün olmayan ve birbiriyle ilişkili istihdam türlerini tanımlamak için kullanılmaktadır. Alışımamış işçiler terimi, kısa vadeli ya da kendi kendini otomatik olarak yenileyen süresiz sözleşmeler imzalayan, taşeron işçilik yapan ve geçici işlerde çalışan işçileri kapsayan bir terimdir. Aslında, serbest çalışanlar, alışılmamış işçilerin bir alt kategorisidir ve bu insanlar, "genellikle, kendi hesabına çalışan; iş, ürün ve hizmetlerini, uzun vadeli bir taahhütte bulunmadan işverenlere satan" işçilerdir (Walters vd., 2006, s. 6). Guy Standing (2011, s. 36), serbest çalışanlar ile kısa süreli sözleşmelerle iş ve gelir güvencesinden yoksun olarak çalışan insanları; esnekleşmiş bir istihdam ortamında, sürekli değişen, geleceği olmayan işlerde, geçici bir statüde, ancak, düzenli olarak çalışan güvencesiz işsizlerden oluşan 'yeni tehlikeli sınıf' olarak tanımladığı prekarya ile özdeşleştirmektedir.

Serbest çalışanlar terimi, freelance-serbest çalışan gazetecileri (stringers, freelance journalists) ve muhabirleri (correspondents) de kapsamaktadır. Freelance gazeteciler, her nerede olursa olsun ürün ve hizmet satarak hayatını kazanan ve herhangi bir örgütsel yapıya mensup olmayan bağımsız gazetecilerdir (Gynnild, 2005, s. 112). Kendi hesabına çalışan freelance gazeteciler, Guy Standing'in (2011, s. 34-35) 'proficians' terimiyle benzerlikler gösteren ve bu terimle eşanlamlı olarak da kullanılabilen 'self-employed' terimine karşılık gelen bir işçi grubu- 
dur. 'Proficians' terimi, kendi hesabına çalışan insanlar olarak kendilerini piyasaya kabul ettirebilmek ve sözleşmeye ya da sözlü anlaşmalara'1 1 dayalı yüksek bir gelir elde etmek için kullandıkları birtakım yetenekler ile emek piyasası oluşturan bir işçi grubunu ifade etmektedir. Bu nedenle, genellikle profesyoneller, uzmanlar ve danışmanlar gibi yüksek maaşı serbest çalışan işçileri tanımlamak için kullanılan 'proficians' terimi, kendi hesabına çalışan (self-employed) gazetecileri de kapsayan bir terimdir.

Mathisen (2017), ikisi arasında mutlak bir ayrım yapmanın mümkün olmadığını belirtmekle birlikte, girişimciler ve idealistler olmak üzere iki farklı freelance gazeteci tipinden bahsetmektedir. Girişimci freelance gazeteciler, yeniliklere açık ve başarı elde etmek için girişimcilik ruhuna sahip gazetecilerdir ve bu gazeteciler, yaptıkları işi ve girişimcilik ruhunun bir sonucu olarak gördükleri iş yapma biçimlerini bir yaşam biçimi olarak tanımlamaktadır. Bu gazeteciler, uzun saatler boyunca çalışarak elde ettikleri gelirden memnundur. Profesyonel olmanın önemini vurgulayan bu gazeteciler, halkla ilişkiler alanında iş yapmaktan kaçınmakta ve yalnızca gazetecilikle ilgilenmektedir. İdealist freelance gazeteciler ise, her zaman onları tatmin eden ücretler almamalarına rağmen, belgeseller, kitaplar, sanatsal ve ticari olmayan projeler gibi gazeteciliğin türleri olan ve yine gazetecilik idealleri ile bağlantıı işler yapmaktadır. Bu gazeteciler, daha düşük gelirlerle idare edebildikleri bir yaşam biçimini tercih etmektedir. Bağımsız çalışma olanağı, onları motive etmektedir. Belki daha da önemlisi, onlar, standart gazeteciliğin ürünü olan haberlerin sınırlarını aşan türlerin ve formatların içinde çalışmaktadır. Baines ve Kennedy (2010) ise, kendi hesabına çalışan gazetecilerle girişimcilik ruhuna sahip gazeteciler arasında bir ayrım yapmaktadır. Onlara göre, kendi hesabına çalışan freelance gazeteciler, işverenlerle bağımlı bir ilişki içindedir ve bu nedenle hem iş ve gelir güvencesinden yoksun hem de güçsüz ve çaresizdir. Ancak, girişimcilik ruhuna sahip olan freelance gazeteciler, bağımsızlık, yetki sahibi olma ve yönlendirilmeme duygusuyla hareket ettikleri için gerçek freelance gazetecilerdir.

Tablo 1. Çalışma ve Iş̧ Yapma Biçimlerine Göre Freelance Gazeteci Tipleri (Kaynak: Elmore ve Massey, 2012, s. 113'ten uyarlanmıştır)

\begin{tabular}{|c|c|c|}
\hline $\begin{array}{c}\text { Yarımgün Çalışan } \\
\text { Freelance Gazeteci }\end{array}$ & $\begin{array}{c}\text { Tamgün Çalışan } \\
\text { Freelance Gazeteci }\end{array}$ & $\begin{array}{c}\text { Kendi İşinin Sahibi ve } \\
\text { Yöneticisi Olan } \\
\text { Freelance Gazeteci }\end{array}$ \\
$\begin{array}{c}\text { Ara sıra iş alan } \\
\text { gazeteciler, asıl işlerine, } \\
\text { tamgün maaş ya da } \\
\text { ücret aldıkları işlerine ek } \\
\text { olarak bu işi yapmaktadır }\end{array}$ & $\begin{array}{c}\text { Kendi hesabına çalışan } \\
\text { gazetecilerin tek ya da asıl } \\
\text { işleri freelance gazeteciliktir }\end{array}$ & $\begin{array}{c}\text { Haber emekçilerini işe alan } \\
\text { gazeteciler, kendi girisimleri } \\
\text { ve yatırımları olan işlerin ve } \\
\text { bu işleri yürüttükleri yerin } \\
\text { sahibidir }\end{array}$ \\
\hline \hline
\end{tabular}

1 Freelance gazeteciler genellikle, sözleşmeler yerine sözlü anlaşmalar aracılığılla çalıştırlıı, onlara haber ya da parça başına ödeme yapilır ve bu durum, gazetecileri, haber endüstrisinde korunmasız bir grup haline getirir (Ladendorf, 2012, s. 83). 
Elmore ve Massey (2012, s. 113-114) ise, freelance gazetecileri, çalışma ve iş yapma biçimlerine göre üç kategoride sınıflandırmaktadır (Tablo 1). Yarımgün çalışan gazetecilerin harcadıkları zaman değişiklik gösterir. Bu grupta yer alan gazetecilerin bazıları ara sıra iş alırken bazıları ikinci bir iş olarak freelance çalışabilmektedir. Bu gazetecilerin freelance çalışma tercihinde bulunmalarının farkı nedenleri vardır. Bazıları, freelance gazeteciliği, gelir elde ettikleri asıl işlerine ek olarak ya da asıl işlerinden tatmin olmadıkları için yapmaktadır. Yaptıkları işler, freelance yazarlıktan, redaktörlüğe, fotoğrafçılığa, web tasarımına ve gazetecilikle ilgili diğer faaliyetlere geniş bir alanı kapsamaktadır. Yarımgün çalışan gazetecilerin aldığı risk asgari düzeydedir. Başlıca gelir kaynakları freelance gazetecilik değildir, herhangi bir finansal kaybın kolaylıkla üstesinden gelebilirler. Çünkü pek çoğu, tamgün çalıştıkları işlerden maaş ya da ücret alabildikleri pozisyonlara sahiptir. Tamgün çalışan gazeteciler, freelance gazetecilik mesleğini, tek başlarına, tamgün ve toptan belirlenen bir ücret karşılığında bir götürü iş olarak yapmaktadır. Bu gazetecilerin asıl ya da tek gelir kaynağı yaptıkları işlerdir. Bu nedenle, daha büyük bir finansal riskle karşı karşıya kalırlar. Finansal bir kaybın kolaylıkla üstesinden gelemezler. Kendi işinin sahibi ve yöneticisi olan gazeteciler ise, bir bankadan ya da sermayedardan ödünç aldıkları sermayeyle ya da bağışlarla, bir blog sayfasına, alternatif bir basılı ya da online gazeteye, bir haber ajansına sahip olan gazetecilerdir. Onlar elinden her iş gelen insanlar olarak hem içerik üreticisidir hem de yayıncı ve yöneticidir. Bu gazeteciler, diğer freelance gazetecilerle işbirliği de yapmaktadır.

Freelance gazeteciler, asıl işleri olan gazeteciliğin dışında ikinci bir istihdam alanı olan halkla ilişkiler alanında da çalışabilmektedir. Romy Fröhlich ve diğerlerine (2013) göre, uluslararası ölçekte paylaşılan bir fikir birliği bulunmaktadır. Buna göre, gazeteciler için halkla ilişkiler, asıl işlerinin dışında çalışabilecekleri ikinci bir iş alanı değildir ve bu bir etik kuraldır. Çünkü halkla ilişkiler faaliyetleri, gazetecilerin bağımsızık, doğruluk, tarafsızlık ve objektiflik noktasındaki sorumluluklarıyla çatışabilmektedir. Ancak, freelance gazetecilere yönelik normatif taleplerle, gazetecilik mesleğinin gerçekliği arasında bir boşluk bulunmaktadır. Profesyonel çalışma koşullarının değişen dünyası gazetecilere meydan okumakta ve bu durum aynı zamanda, halkla ilişkiler alanında çalışan freelance gazeteci sayısının giderek artmasına neden olmaktadır. Ayrıca, yine Romy Fröhlich ve diğerlerine (2013) göre, resmin böyle olup olmadığı ve eğer böyleyse, halkla ilişkiler alanında ikinci bir iş yapan freelance halkla ilişkiler gazetecilerinin, bu iş alanı hakkında ne düşündükleri ve her iki alan arasındaki çatışmayı nasıl kabullendikleri henüz derinlemesine incelenmemiştir.

\section{Diğer Ülkelerdeki Araştırmaların Bulguları}

Freelance gazeteciliğin yaygınlaşmasıyla birlikte, bu alana gösterilen akademik ilginin sınırlı da olsa artı̆̆ı görülmektedir. Bu kapsamda ilgili alanyazının incelenmesi, alana özgü akademik çalışmaların haritasını çıkarabilmek için önemlidir. Mathisen (2017), girişimciler ve idealistler olmak üzere iki farklı freelance ga- 
zeteci tipine vurgu yaptığı çalışmasında, gazetecilerin profesyonel rolünü açıklığa kavuşturmayı amaçlamış ve gazetecilerin tecrübe ettikleri gelir güvencesinden yoksun olma durumunun beraberinde getirmiş olduğu kısıtlamalara karşı bağımsızlık ve özgürlük arasındaki gerilimi tartışmaya açmıştır. Söz konusu tartışmayı, on beş Norveçli freelance gazeteciyle gerçekleştirdiği niteliksel görüşmelere dayandırmıştır. Maria Edström ve Martina Ladendorf (2012) ise, İsveçli freelance gazetecilere ilişkin hem niceliksel hem de niteliksel bulgulara dayanan çalışmalarında, periyodik araştırmaların sonuçlarına yer vermiştir. Niceliksel bulgular, Gothenburg Üniversitesi'nde görev yapan araştırmacılar tarafından 1989, 1994, 1999 ve 2005 yıllarında, aktif gazetecilik yaşamlarına devam eden gazetecilerin temsili bir örneklemi ile gerçekleştirilen periyodik anketlerden elde edilmiştir. Her ankete ortalama 2000 gazeteci katılmıştır. Niteliksel bulgular ise, İsveç'in kuzeyinde, on üç freelance gazeteciyle gerçekleştirilen bibliyografik görüşmelerden elde edilmiştir. Bu bulgular, uluslararası çalışmalarla karşılaştırılmıştır. Bu araştırmayla, bir freelance gazeteci olarak çalışma tercihinde bulunmanın, yaşam biçimi ve bir proje olarak yaşam fikriyle ilişkilendirildiği görülmüştür. Gazeteciler, freelance çaIışmanın bir yaşam biçimi ve bu tercihin bir proje olarak görülen yaşamla bire bir ilişkili olduğunu ifade etmiştir. Ayrıca, freelance çalışma pratiği, gazeteciler tarafından hem girişimcilik ruhu hem de bireyselleşme ile esnekleşme gibi toplumsal süreçlerle bağlantılı olan tercihlerle ilişkilendirilmiştir.

Ladendorf (2012) da gazetecilik ve halkla ilişkiler arasındaki sınıın bulanık olduğunu ve özellikle freelance gazeteciler arasında bu durumun farkındalık yarattığını öne sürmüştür. Bu bulanıklığın, freelance gazetecileri ve özellikle, bu gazetecilerin etik muhakeme süreçlerini² 2 nasıl etkilediğini araştırdığı çalışmasında, İsveç'in kuzeyinde yer alan periferik bir bölgede yaşayan on üç freelance gazeteci ile gerçekleştirdiği görüşmelerin sonuçlarını paylaşmıştır. Araştırma sonucunda, doğruluk ve tarafsızlık gibi profesyonel rollerini sürdürmek ve öz kimliklerini güçlendirmek için gazetecilerin, halkla ilişkiler faaliyetleri ile gazeteci rolleri arasında bir sınır çizmelerinin çok önemli olduğunu vurgulamıştır. Buna kanıt olarak da gazetecilerin kişisel etik anlayışlarının, profesyonel ilkelerin yerine geçmesini göstermiştir. Öyle ki freelance gazeteciler; meslek ideallerinin ve kurallarının gazetecilerin kişisel eylem etiğinin arka planını oluşturduğu bir iş ortamında, gündelik çalışma koşullarıyla birlikte, haber endüstrisinin kısıtlamalarına refleks olarak karşı çıkmaktadır. De Cock ve de Smaele (2016), Belçika'nın Flaman bölgesinde gerçekleştirdikleri çalışmalarında, her beş profesyonel gazeteciden birinin, freelance gazeteci olduğunu ortaya koymuştur. Ayrıca, bu çalışmada, sözleşmeye bağlı olarak yerleşik bir haber merkezinde çalışan gazetecilerin yüzde doksan üçünün, freelance gazetecilerin ise yalnızca yarısının mesleklerinden memnun olduğu görülmüştür. Bununla birlikte, araştırma sonucunda, freelance gazeteciliğe ilişkin belirli bir avantajlar ve dezavantajlar listesinin mevcut olmadığı ifade edilmiştir.

2 Freelance gazetecilik söz konusu olduğunda, etik sorunlar ortaya çıkabilmektedir. Freelance gazetecilerin yaşamlarındaki belirsizlikler, onları, etik olarak affedilmez olan işleri kabul etmeye zorlayabilir (Ladendorf, 2012, s. 91). 
Avery E. Holton (2016) çalışmasında, Amerika Birleşik Devletleri'nde, on dokuz freelance gazeteci ve dokuz gazete editörü ile gerçekleştirilen yarı yapılandırılmış görüşmelerden elde edilen bulguları gözler önüne sermiştir. Bu çalışma, gazetecilerin, kendi izler kitlesiyle yakın bir ilişki kurmak ve kişisel markasını oluşturmak için sosyal medyadan yararlandığını ortaya koymuştur. Çalışmada, editörlerin, haber merkezindeki pratikler ve izler kitle katılımı hakkında bilgilendirici olan kurumsal stratejileri takip etme şansına sahip oldukları ve bu stratejilere dâhil ettikleri sosyal medya platformlarını, freelance gazetecilerin de kullandıkları görülmüştür. Hunter (2015), Kanada ve Amerika Birleşik Devletleri'nde, yirmi bir freelance gazeteci ile gerçekleştirdiği görüşmeler sonucunda, topluluk sermayesi ile finanse edilen gazetecilerin, bir gazetecilik kuralı olarak bağımsızlığa güçlü bir şekilde inandıklarını belirlemiştir. Fakat aynı zamanda, gazetecilerin, potansiyel bir çatışma noktası olarak kabul edilen finans sağlayıcı kişilere karşı da büyük ölçüde sorumluluk hissettiklerini öne sürmüştür. Ayrıca, Hunter'a (2015) göre bir bakış açısıyla ya da savunucu gazetecilik yapmak için topluluk sermayesi kullanan gazeteciler, bir gazetecilik kuralı olarak objektifliği reddetmektedir. Hunter (2016), Amerika Birleşik Devletleri ve Kanada'da, topluluk sermayesi yaratan iş ortamlarından yirmi dört Amerikalı ve üç Kanadalı freelance gazeteci ile gerçekleştirdiği görüşmelerin bulgularına yer verdiği bir başka çalışmasında, şu değerlendirmeleri yapmıştır. Topluluk sermayesi yaratmak, işgücünü ve gazetecilik faaliyetlerini finanse etme noktasında etkili olabilmekte ve bu finans yapısı, geleneksel haber kuruluşları dışında çalışabilme şansına sahip olan gazetecileri özgürleştirmektedir. Massey ve Elmore (2011), Amerika Birleşik Devletleri'nde, kendi hesabına çalışmak için geleneksel işveren odaklı gazetecilik mesleğini terk eden kadın freelance gazetecilere, bir internet anketi uygulamıştır. Araştırmanın bulguları, kadın katılımcıların, çalışma saatlerinden, elde ettikleri gelirden ve çocuklarını yetiştirirken bu alışılmamış gazetecilik işini yapmaktan memnun olduklarını göstermiştir. Ayrıca bu kadın freelance gazetecilerin, erkek gazetecilerden daha fazla mesleki tatmin duygusu yaşamadıkları görülmüştür.

Romy Fröhlich ve diğerleri (2013), ikinci bir iş olarak halkla ilişkiler alanında çalışan freelance gazetecilerle ilgili araştırmaların yetersiz olduğunu belirtmektedir. Bu boşluğu doldurmak için Almanya'da gerçekleştirdikleri çalışmalarında, eşzamanlı olarak halkla ilişkiler alanında çalışan freelance gazetecilerin, öncelikli olarak birbiriyle çatışan rolleri (çatışmayı algılama biçimleri) arasında nasıl uzlaşı sağladıklarını ya da bu roller arasındaki çatışmayla nasıl başa çıkabildiklerini araştırmıştır. Eşzamanlı olarak halkla ilişkiler müşterileri için çalışan on sekiz freelance gazeteci ile gerçekleştirilen yarı yapılandııımış görüşmelerden elde edilen bulgular, gazetecilerin hem çatışma potansiyelinin farkında olduklarını hem de gazeteciler olarak öz benliklerini koruma eğiliminde olduklarını göstermiştir. Magdalena Obermaier ve Thomas Koch (2015) ise gazetecilik faaliyetlerinin yanı sıra, halkla ilişkiler alanında çalışan 1248 Alman freelance gazeteci ile gerçekleştirdikleri niceliksel online ankette, gazetecilerin, sıklıkla birbiriyle çatışan rolleri nedeniyle sıkıntı yaşadıklarını ortaya çıkarmıştır. Gazeteciler, kendilerini bazen gazeteci bazen de halkla ilişkiler uygulayıcısı olarak görmekte ve bu nedenle, bir belirsizliğin içinde 
stres yaşamaktadır. Gazetecilerin halkla ilişkiler alanında çalışmamaları gerektiğine dair normatif bir algı içselleştirilmiş olmakla birlikte, gazeteciler, birbiriyle çatışan rollerin sonuçlarını daha yoğun tecrübe etmekte ve iş yaşamında daha stresli bir sürecin parçası haline gelmektedir. Ayrıca, freelance halkla ilişkiler gazetecileri, rol çatışması içinde, daha az mesleki tatmin duygusu yaşamaktadır.

Solomon (2016) ise, haber merkezlerinin küçüldüğünü, ancak, artık kısmen de olsa, freelance gazeteciler sayesinde gazeteciliğe ilişkin daha fazla seçeneğe sahip olunduğunu ve freelance çalışma pratiğinin, özellikle farklı alanlara adapte olabilen, kreatif haber emekçilerinin önünde bir yol açtığını öne sürmüştür. Türkiye, Mısır, Kolombiya, İsrail, Kanada, Kenya, Fransa, Almanya ve Amerika Birleşik Devletleri'ndeki elliden fazla freelance gazeteci ile gerçekleştirdiği görüşmelerin ve anketlerin sonucunda, iyi gazetecilik yapmak için intiyaç duyulan temel becerilerin değişmediğini, ancak, değişen iş modellerini bilmenin ve bu modelleri takdir etmenin önemli olduğunu ifade etmiştir. Ayrıca, Solomon'a (2016) göre, freelance gazeteciler, gazetecilik öğrencilerine gazeteciliğe ilişkin bilinmesi gereken tüm detayları yavaş yavaş aşılayabilecek yeterliliklere sahip eğitimciler olarak da görülebilmektedir. Ona göre, bağımsız ve girişimci freelance gazeteciler; gazetecilik öğrencilerinin, öngörülemeyen zorluklarla mücadele edebilmeleri için onları bu süreçte başarılı olmaya teşvik edecek fikirlere de sahip olmalıdır.

\section{Metodoloji}

Araştırmada, freelance gazeteciliğin hem profesyonel gazeteci kimliğinde ve pratiklerinde yarattığı dönüşümü gözler önüne serebilmek hem de bu alanda ortaya çıkan temel sorunlara işaret etmek amacıyla, derinlemesine görüşme yöntem ve tekniği uygulanarak on yedi freelance gazeteci ile görüşülmüştür. Derinlemesine görüşmede, katılımcılara; görüşlerini, düşüncelerini, fikirlerini, deneyimlerini ve perspektiflerini öğrenmek için açık uçlu sorular sorulmakta, yanıtlar kaydedilmekte ve ek sorularla araştırma konusu ayrıntılı bir şekilde sorgulanmaktadır. Bu yöntem ve tekniği kullanan bir araştırmacı, anketlerde ya da odak grup çalışmalarında elde edilen bilgiden çok daha derin bir bilgi edinebilmektedir (Johnson ve Rowlands, 2012, s. 100). Bu yöntem ve teknik kapsamında, daha önce de belirtildiği gibi, katılımcılara, üç ana tema kapsamında toplanabilecek yarı yapılandııımış derinlemesine görüşme soruları sorulmuştur. Sorular, freelance gazeteciliğin mevcut durumu, geleceği ve geleneksel haber kuruluşları ile meslek pratiklerinde yarattığı dönüşüme ilişkin sorulardır. Görüşmelerin gerçekleştiği Mayıs 2018-Ağustos 2018 tarihlerini kapsayan dört aylık süreçte, sorular, telefon acıığıyla sorulmuş ve görüşmeler tamamlanmıştır. Görüşmelerin tamamı, gazetecilerin farklı şehirlerde ikamet etmeleri ve mobil bir yaşam sürdürmeleri nedeniyle aynı mekânda yüz yüze gerçekleştirilememiştir. Telefon aracılığıyla yapılan görüşmeler kayıt altına alınarak deşifre edilmiştir.

Türkiye bağlamında, freelance gazetecilik pratiğini; süresiz istihdam olanağına sahip olmayan ya da birkaç işverenle çalışan ve bireysel işler alan fre- 
elance gazetecilerin gerçekleştirdiği bir pratik olarak tanımlamak mümkündür. Bu nedenle, araştırmada, freelance gazeteciler örneklemi, kısa ya da uzun vadeli sözleşmelerle çalışmayan, birkaç işveren için işler alan ve kendi hesabına çalışan gazetecilerle sınırlandırılmıştır. Dolayısıyla, araştırmada, kısa vadeli sözleşmelerle çalışan geçici işçiler statüsündeki gazeteciler örnekleme dâhil edilmemiştir. Tablo 2 'de görüşme yapılan freelance gazetecilerin cinsiyetine, yaşına, eğitim düzeyine ilişkin bilgilere ve freelance gazetecilik faaliyetlerini gerçekleştirdikleri çalışma alanlarına (uzmanlık konuları) yer verilmiştir. Bu araştırma için alanyazındaki bazı çalışmaların örneklemlerinde olduğu gibi yalnızca profesyonel gazetecilerle görüşülmüştür. Editörlerle herhangi bir görüşme yapılmamıştır. Görüşmelere katılan on yedi gazetecinin tamamı Türkiye Cumhuriyeti vatandaşı, Türkiye'de ikamet eden ve sürekli ülke sınırları içinde gazetecilik faaliyetleri yürüten gazetecilerdir. Türkiye Cumhuriyeti vatandaşı olmayan, ancak, oturma ya da çalışma izni olduğu için Türkiye'de ve farklı ülkelerde gazetecilik faaliyetleri yürüten yabancı gazetecilerle görüşme yapılmamıştır. Ayrıca, online erişimin mümkün olduğu ve topluluk sermayesi yaratma alanları olarak kabul edilen online haber sitelerinde çalışan gazetecilerle de görüşme yapılmamıştır. Görüşmelere katılan freelance gazetecilerin 12'si erkek ve 5'i de kadındır.

Derinlemesine görüşmelerde, sorulara verilen yanıtlara ek olarak yeni sorular da sorulmuştur. Görüşmeler, 20 ile 50 dakika sürmüştür. Ortalama süre, 30 dakikadır. Yarı yapılandırımış soruların sorulduğu görüşmelerin amacı, katılımcılara, özellikle konuyla ilgili fikirlerini tartışmak için bir alan açmak ve araştırmayla ilgili tema ve konuları incelemektir. Görüşme soruları, katılımcıların, freelance gazeteciliğe ilişkin motivasyonlarını, deneyimlerini ve bu gazetecilik türünün doğasına ilişkin düşüncelerini ifade etmeleri için onları teşvik etmek amacıyla tasarlanmıştır. Aynı zamanda, görüşme yapılan gazeteciler, tartışma konularını genişletmeleri ve özellikle araştırmacının, hakkında sorular sormadığı yeni fikirlerden bahsetmeleri için cesaretlendirilmiştir. Zaten, Johnson ve Rowlands'ın (2012, s. 100) da ifade ettiği gibi, derinlemesine yarı yapılandırımış görüşmelerin amacı, katılımcının 'yaşanmış deneyimini', 'değerlerini ve kararlarını', 'mesleki ideolojisini', 'kültürel bilgisini' ya da 'perspektifini' anlatmasını sağlamaktır.

Bu araştırma, Türkiye'de, freelance gazetecilik alanının; freelance gazetecilerin mesleki haklarının korunması, iş ve gelir güvencesinden yoksun kalma riskinin ortadan kaldırıması ve çalışma koşullarının iyileştirilmesi noktasında, başta kamu kurum ve kuruluşlarıyla birlikte devletin, meslek örgütlerinin ve sendikaların güvencesi altında olmadığını varsaymaktadır. Ayrıca, freelance gazetecilerin başarılı olmak için profesyonel kimlik bağlamında sahip olması gereken özellikler (ön koşullar) tartışma konusudur ve bir freelance gazeteci olarak çalışmanın (dez) avantajlarına ilişkin belirli bir listeden bahsetmek mümkün değildir (De Cock ve de Smaele, 2016). Alanyazın taramasına dayanan ve Türkiye'de faaliyet gösteren freelance gazetecilerle derinlemesine görüşmelerin gerçekleştirildiği bu niteliksel araştırma, üç araştırma sorusu üzerine inşa edilmektedir: 
Tablo 2: Görüşme Yapılan Freelance Gazetecilere Illişkin Bilgiler (Katıımcıların adı ve soyadı deşifre edilmemektedir)

\begin{tabular}{|c|c|c|c|c|c|}
\hline $\begin{array}{c}\text { Freelance } \\
\text { Gazeteci No }\end{array}$ & Cinsiyet & Yaş & $\begin{array}{l}\text { Eğitim } \\
\text { Düzeyi }\end{array}$ & $\begin{array}{c}\text { Klasik } \\
\text { Gazetecilik } \\
\text { Eğitimi } \\
\text { (Evet/Hayır) }\end{array}$ & $\begin{array}{c}\text { Freelance } \\
\text { Gazetecilik Çalışma } \\
\text { Alanı } \\
\text { (Uzmanlık Konusu) }\end{array}$ \\
\hline $\begin{array}{c}\text { Freelance } \\
\text { Gazeteci (1) }\end{array}$ & Erkek & 29 & Lise & Hayır & Yok \\
\hline $\begin{array}{c}\text { Freelance } \\
\text { Gazeteci (2) }\end{array}$ & Erkek & 39 & Lise & Hayır & Yok \\
\hline $\begin{array}{c}\text { Freelance } \\
\text { Gazeteci (3) }\end{array}$ & Erkek & 33 & Lise & Hayır & Yok \\
\hline $\begin{array}{c}\text { Freelance } \\
\text { Gazeteci (4) }\end{array}$ & Erkek & 31 & Üniversite & Evet & Sinema \\
\hline $\begin{array}{l}\text { Freelance } \\
\text { Gazeteci (5) }\end{array}$ & Kadın & 27 & $\begin{array}{c}\text { Üniversite } \\
\text { Master- } \\
\text { Devam Ediyor }\end{array}$ & Evet & $\begin{array}{c}\text { Kadın ve Çocuk Hakları } \\
\text { Kent ve Çevre } \\
\text { Haberciliği } \\
\text { Atatürk Arastırmaları }\end{array}$ \\
\hline $\begin{array}{c}\text { Freelance } \\
\text { Gazeteci (6) }\end{array}$ & Erkek & 27 & Üniversite & Hayır & Barış Gazeteciliği \\
\hline $\begin{array}{l}\text { Freelance } \\
\text { Gazeteci (7) }\end{array}$ & Erkek & 27 & $\begin{array}{c}\text { Üniversite } \\
\text { Master- } \\
\text { Devam Ediyor }\end{array}$ & Evet & $\begin{array}{c}\text { Spor } \\
\text { Aktüel Olaylar }\end{array}$ \\
\hline $\begin{array}{l}\text { Freelance } \\
\text { Gazeteci (8) }\end{array}$ & Kadın & 34 & $\begin{array}{l}\text { Üniversite } \\
\text { Master }\end{array}$ & Evet & $\begin{array}{c}\text { Ekonomi } \\
\text { Sağlık } \\
\text { Çalıșma Hayatı }\end{array}$ \\
\hline $\begin{array}{c}\text { Freelance } \\
\text { Gazeteci (9) }\end{array}$ & Kadın & 21 & Üniversite & Evet & $\begin{array}{c}\text { Özel Haber } \\
\text { Kültür ve Sanat }\end{array}$ \\
\hline $\begin{array}{c}\text { Freelance } \\
\text { Gazeteci (10) }\end{array}$ & Erkek & 51 & Üniversite & Evet & Uluslararası İlişkiler \\
\hline $\begin{array}{c}\text { Freelance } \\
\text { Gazeteci (11) }\end{array}$ & Erkek & 27 & Üniversite & Hayır & $\begin{array}{l}\text { Teknoloji } \\
\text { Güvenlik }\end{array}$ \\
\hline $\begin{array}{c}\text { Freelance } \\
\text { Gazeteci (12) }\end{array}$ & Kadın & 47 & $\begin{array}{l}\text { Üniversite } \\
\text { Master }\end{array}$ & Evet & $\begin{array}{l}\text { Diplomasi } \\
\text { Dış Politika } \\
\text { Savunma }\end{array}$ \\
\hline $\begin{array}{c}\text { Freelance } \\
\text { Gazeteci (13) }\end{array}$ & Erkek & 40 & $\begin{array}{l}\text { Üniversite } \\
\text { Master }\end{array}$ & Evet & $\begin{array}{c}\text { Suriye } \\
\text { Türkiye Siyaseti }\end{array}$ \\
\hline $\begin{array}{c}\text { Freelance } \\
\text { Gazeteci (14) }\end{array}$ & Erkek & 32 & Üniversite & Hayır & Kültür ve Sanat \\
\hline $\begin{array}{c}\text { Freelance } \\
\text { Gazeteci (15) }\end{array}$ & Erkek & 23 & Üniversite & Evet & Özel Haber \\
\hline $\begin{array}{c}\text { Freelance } \\
\text { Gazeteci (16) }\end{array}$ & Erkek & 46 & Üniversite & Hayır & $\begin{array}{c}\text { Ortadoğu } \\
\text { Çatışma Çözümleri }\end{array}$ \\
\hline $\begin{array}{c}\text { Freelance } \\
\text { Gazeteci (17) }\end{array}$ & Kadın & 28 & $\begin{array}{c}\text { Üniversite } \\
\text { Master }\end{array}$ & Evet & Televizyon \\
\hline
\end{tabular}


Araştırma Sorusu (1): Türkiye'de freelance gazetecilik yapmak için gazetecilerin sahip olması gereken özellikler (ön koşullar) var mıdır ve eğer varsa nelerdir?

Araştırma Sorusu (2): Türkiye'de bir freelance gazeteci olarak çalışmanın (dez)avantajları nelerdir?

Araştırma Sorusu (3): Türkiye'de freelance gazetecilik alanındaki temel sorunlar nelerdir? Freelance gazeteciler çalışma koşullarından memnun mudur? Memnuniyet(sizlik)lerinin nedenleri nelerdir?

\section{Bulgular}

Büyük bir kısmı yükseköğrenim düzeyinde klasik gazetecilik eğitimi almış ve farklı uzmanlık konularında gazetecilik faaliyetlerini sürdüren profesyonel freelance gazetecilerin derinlemesine görüşme sorularına verdikleri yanıtlar, daha önce belirtilen üç ana tema kapsamında kategorileştirilmiştir.

\section{Profesyonel Kimlik}

Araştırma öncelikle freelance gazetecilerin mesleki yaşamlarına odaklanmıştır. Görüşmelerde, katılımcılar, mesleki yaşamlarındaki değişiklikler, işverenlerle ilişkileri ve gazetecilik mesleğine ilişkin tutumları hakkında detaylı açıklamalar yaparak profesyonel kimliklerini tanımlamıştır. Türkiye'de, freelance gazetecilerin profesyonel kimliğini inşa eden temel unsurlar bir katılımcı tarafından şöyle açıklanmıştır:

Freelance Gazeteci (13): Türkiye'de freelance gazetecilik daha çok yabancı basına mihmandarlık/saha prodüksiyonu yapmak üzerine kurulu. Yurtdışındakine benzer bir freelance çalışma ortamı pek yok. Al Jazeera Türk'te kadrolu olarak çalıştığım dönem freelance muhabir/fotoğrafçılarla çalışıyorduk, onlar telif karşılığı dosya, haber ya da fotoğraf sunuyordu. Ben ve benim gibi freelance çalışan Türk gazetecilerin yüzde 90'ıysa gelen yabancı gazetecilere içerik, lojistik, çeviri, saha prodüksiyonu, fixer ${ }^{33}$ 'lık gibi konularda yardımcı oluyor. Dolayısıyla, öncelikle yabancı dil bilmek, saha deneyimine sahip olmak, Türkiye'deki siyasi, toplumsal ve ekonomik gelişmelere hâkim olmak, kabarık bir telefon rehberine sahip olmak, görsel malzeme üretimi ve sunumu konusunda deneyimli olmak, gelen yabancı ekip adına röportaj yapabilecek, onun adına sorular sorup gelen cevaba karşı o soruları çeşitlendirebilecek seviyede çalışılan konu üzerinde sorumluluk ve hâkimiyet sahibi olmak, bu kimliği oluşturan temel unsurlardan bazıları. Ekibe konuyla ilgili arka plan bilgisi verebilecek donanım ve deneyime sahip olmak ve bunu onların anlayabileceği şekilde formüle edebilmek de Türkiye'deki freelance gazeteciler için belirleyici.

Aynı katılımcı, Türkiye'de, bir freelance gazetecinin eğitim düzeyinin ve yaşının başarılı olmak için bir önkoşul olmadığını, ancak, her ikisinin de gazeteciler için birer artı olduğunu ifade etmiş ve bunun nedenlerini şöyle açıklamıştır:

3 Bu İngilizce kelimenin Türkçe anlamı, iş bitirici, saptayan ya da düzenleyicidir. Ülkeye ya da bölgeye gelen yabancı gazeteciler için bağlantı sağlayan ve onlara rehberlik ve çevirmenlik yapan kişiler fixer olarak adlandııııyor. Bu işi yapanların pek çoğu ya eski gazetecilerdir ya da yerel medya çalışanlarıdır. 
Freelance Gazeteci (13): Bir önkoşul olduğunu düşünmüyorum, ama mutlaka artıları vardır bu unsurların. Çok daha az deneyimli ama parlak genç arkadaşların meslek büyüklerine göre daha iyi işler yaptığına şahit oldum, ama bu durum bir istisna. Gazetecilik daha çok birikimle ilgili bir meslek. Deneyimli gazetecinin hata yapma olasılığı daha düşük. Çünkü o hataları zaten deneyimsizken yaptı, deneyim dediğimiz şey zaten geçmişte yaptığımız hataların toplamı. Eğitim düzeyi konusu da aslında biraz bununla ilgili. Mutlaka iletişim fakültesi mezunu olmalı gibi bir düşüncem yok, hatta farklı disiplinlerden gelen gazetecilerin genelde daha başarılı olduğunu gözlemliyorum. Lisansüstü eğitim yapmış olanların da yapmamış olanlara göre daha iyi işlere imza attığını düşünüyorum, zira lisansüstü eğitim araştırmacılık melekelerini geliştiriyor. Bir önkoşul mudur? hayır, ama kesinlikle bir artıdır.

Bir freelance gazetecinin belirli bir alanda uzman olmak zorunda olup olmaması tartışma konusudur. Ancak, freelance gazetecinin ekstra yeteneklere ve becerilere sahip olması gerektiği katılımcılar tarafından sıklıkla tekrarlanmıştır.

Freelance Gazeteci (16): Elbette uzmanlık önemli. Eğer bu coğrafyada freelance gazetecilik yapacaksanız hem Türkiye'nin hem de Ortadoğu ülkelerinin siyasi, ekonomik ve beșerî coğrafyasını iyi bilmek zorundasınız. Diğer yandan telefon rehberinizin de kalabalık olması, yerli ve yabancı haber kaynaklarına kolayca ulaşabilir olmanız gerekir. Dolayısıyla, sıradan bir gazetecilik geçmişi size çok fazla yardımcı olmayabilir. Fakat konuşabildiğiniz diller, mesleğinize bağlı̆ğınız önemli.

Freelance Gazeteci (14): Belirli bir alanda uzman olmak imzanızın değerini artırır. Ama hayatta kalacak kadar para kazanmak için uzmanlık şart değil.

Freelance Gazeteci (11): Belirli alanlarda uzman olmak bir zorunluluk olmasa da, o alanda yaptığı haberlerle bilinen birisi olmak iş bulma konusunda bir avantaj sağlayacaktır. Her ne kadar kişisel olarak birkaç alanda uzman olarak görülsem de bu benim kendimi geliştirmeme ve ilgimi çeken diğer alanlarda çalışmama engel olmuyor.

Freelance Gazeteci (17): Bir freelance gazeteci belli bir konuda uzmanlaşmak isteyebilir, ama birçok konuda bilgi, beceri ve donanıma sahip olmalıdır ... Bazen hiç bilmediğimiz ve etkin olmadığımız bir konuda çalışmak zorunda kalıyoruz ve o konuyu kavramak ve kaynaklarla iletişime geçmek için zaman kaybediyoruz.

Freelance Gazeteci (12): Evet, özellikle yeni dönemde, ekonomi, teknoloji, tarım ve sağlık alanlarında uzmanlık, eğitim ve dış politika gibi alanlarda da yoğun bilgi gerekli.

Freelance Gazeteci (9): Freelance gazetecilerin belli bir alanda uzmanlaşması gerektiğine inanmıyorum ... Evet, gazetecinin akla gelebilecek çoğu şey hakkında, az da olsa bilgili olması gerekir. Fakat bir alanda aşırı yoğunlaşmanın gazeteciyi, alan gazetecisine dönüştürebileceği görüşündeyim.

Gazetecilik mesleğini bir yaşam biçimi olarak tanımlayan ya da benimseyen katılımcıların tamamına yakını gazeteciliğin kendileri için bir vazgeçilmez ve hatta benliklerinin bir parçası olduğunu belirtmektedir. Ancak, görece daha az sayıda gazeteci, mesleğin kendileri için bir vazgeçilmez olmadığını ifade etmektedir.

Freelance Gazeteci (1): Gazetecilik hayatımın bir parçası ... Alışmış olduğum bir yaşam biçimi diyelim. Her şartta ve ortamda gazeteci kimliğimden vazgeçmem. Severek yapıyorum ve sonuna kadar bu mesleğe devam edeceğim. 
Freelance Gazeteci (3): On iki yıldır gazetecilik yaptığım için neredeyse hayatımın her alanına girmiş. Bu nedenle sanırım vazgeçilmez oldu.

Freelance Gazeteci (5): Mesleğim benim için her zaman vazgeçilmez oldu ... Deneyimlediğim başka hiçbir işte kendimi bu kadar amacıma uygun ve amacımı gerçekleştiriyor hissetmedim ... Sanırım ben bu mesleği sadece bir iş olarak görenlerden değilim. Benliğimin bir parçası olarak hissediyorum.

Freelance Gazeteci (6): ... gazetecilik benim için bir yaşam biçimidir.

Freelance Gazeteci (7): ideallerimi, hayat gayemi savunma ve kendimi gerçekleştirme noktasında gazetecilik benim için çok önemli. Vazgeçilmezim diyemem ama benim için çok önemli.

Freelance Gazeteci (10): Gazetecilik benim için vazgeçilmez değil. Otuz yıllık bir deneyimle, yeteri kadar doyuma ulaştığım için.

Katılımcıların büyük bir kısmı gazetecilik mesleğinden vazgeçmeyeceklerini belirtseler de, bazı katılımcılar, özellikle ekonomik nedenlerle bir freelance gazeteci olarak çalışmak yerine başka bir iş yapmayı düşündüklerini dile getirmiştir. Bazı katılımcılar, bir freelance gazeteci olarak çalışmanın bir tercih, bazıları, bir zorunluluk olduğunu dile getirirken, bunun nedenlerini şu sözlerle ifade etmiştir:

Freelance Gazeteci (4): Ekonomik koşullardan dolayı düşündüm. Çünkü freelance gazetecilik bir kişinin ekonomik olarak kendini geleceğe taşıması için yeterli imkânları sunmuyor.

Freelance Gazeteci (13): Mevcut medya iklimi nedeniyle bir şekilde işsiz bırakıldığım için zorunluluk, ama gazetecilikten henüz vazgeçmediğim için tercih. Bugünün koşulları altında freelance gazetecilik dışında gazetecilik düşünmem. Ama idealin bu olmadığı da kesin, gerçek gazeteciliğin yapılabildiği bir zamanda/ mekânda yaşıyor olsaydık kesinlikle kurumsal bir organizasyonda kadrolu olarak çalışmak isterdim.

Freelance Gazeteci (15): Bu bir tercih. Kimsenin zoruyla yapılmaz.

Freelance Gazeteci (2): Freelance çalışma hem tercih hem de sarı basın kartı olmayanlar için zorunluluk.

Freelance Gazeteci (8): Türkiye koşullarında çoğunlukla zorunluluk.

Freelance Gazeteci (14): Zorunluluk. Küçülen sektör herkesin malumu.

Freelance Gazeteci (16): ... freelance gazeteci olarak çalışmaya bir zorunluluk ile başladım. Zira düzenli olarak çalıştığım kurum kapanmak üzereydi. Yeni bir yapılanmaya gidilince işten ayrılmak zorunda kaldım. Bu nedenle, freelance gazeteci olarak yabancı basın kuruluşları için çalışmaya başladım.

Freelance Gazeteci (17): ... beni sigortalı işe alacak hiçbir medya kurumu bulamadım. Ve hayatımı idare ettirmek ve faturalarımı ödeyebilmek için freelance çalışmak zorundaydım. Fakat şu an bir zorunluluk değil, bir tercih haline geldi, ... kimsenin boyunduruğu altına girmeden kendi tercih ettiğim medya kuruluşları ile çalışmamı sağladı ve şu anda kesinlikle bir tercih.

Türkiye'de geleneksel haber kuruluşlarının ekonomik nedenlerle kapanması ve sektörün daralması, gazetecileri iş ve gelir güvencesinden yoksun bırakmakta ve onları freelance gazetecilik yapmaya zorlamaktadır. Ancak, bütün bunlara rağmen, bazı gazeteciler, freelance gazeteciliği özellikle tercih etmekte ve bunu bir fırsat olarak görmektedir. 


\section{(Dez)avantajlar}

Freelance gazetecilik özellikle iki farklı konuda avantajıdır. Freelance gazeteciler hem kişisel tercihleri doğrultusunda herhangi bir işveren ya da aynı anda birkaç işveren için iş yapma özgürlügüne sahiptir hem de kişisel bir marka sahibi olmanın başarılı olmak için bir zorunluluk olduğunu bilmektedir. Ancak, freelance gazetecilik, özellikle iş ve gelir söz konusu olduğunda dezavantajıdır. Bütün bunların ötesinde, başka (dez)avantajlar da söz konusudur. Türkiye'de bir freelance gazeteci olarak çalışmanın (dez)avantajları iki katıımcı tarafından şöyle açıklanmıştır:

Freelance Gazeteci (13): Yabancı bir kurum için çalışıyorsanız daha bağımsız habercilik yapabilme imkânı; mesai saatlerinden bağımsız çalışabilmek, iş/gün/ saat hesabıyla çalışıldığı için birim başına daha yüksek ücret ve daha çok boş vakit.

... haberin asli unsuru olmamak. Imzalarımızın yer almaması ya da nadiren yer alması. Bu aslında biraz ucuz iş gücü olmaya benziyor; Türkiye haber üretiminin Çin'i ve biz de birer isimsiz işçiyiz. Zaman zaman kendi imzalarımızla yaptığımı işler oluyor elbette, ama sağlıkı bir gazetecilik ortamı olsaydı eğer Türk medyasında çalışır, kendi işlerimizi kendi imzalarımızla, kendi toplumumuza sunabilirdik.

Freelance Gazeteci (11): En büyük avantajı, ülkemizde basının pek de özgür olmayan koşullarında en azından bir parça daha özgür hareket edebilme ve çalışabilme imkânı sağlıyor olması. Bir kuruma bağlı olarak çalışmanın getirebileceği oto sansür, işinden sebepsiz ya da geçersiz sebeplerle çıkarılma gibi şeyleri yaşamak durumunda kalmıyor olmak ve herhangi bir kurumsal yapının yayın politikası içerisinde kısıtlanmadan çalışabilme şansına sahip olmak.

En başta hala kimi kesimlerde ve özellikle devlet ve özel kurumlarda gazeteciliğimizi kabul ettiremiyoruz. Bir kuruma bağlı çalışmadığımız için ya da devletin verdiği sarı basın kartına sahip olmadığımız için gazeteci olarak görülmüyoruz. Bununla birlikte, freelance gazetecilere ücretsiz muhabir gözüyle bakan kurumlar yüzünden ciddi sıkıntılar yaşıyoruz. Ödeme alabilmek büyük sıkıntı, özellikle zamanında almak neredeyse imkânsız gibi. Ayrıca, emeğimizin karşılığını almakta zorlanmamıza rağmen, freelance gazetecilere çok fazla iş yükleniyor. Son olarak, birçok kurum, freelance çalışanları ile nasıl ilişki kurdukları, nasıl haber kabul ettikleri, ne kadar ödeme yaptıkları gibi şeyleri hiçbir şekilde ulaşılabilir kılmıyor, büyük bir kısmı da zaten freelancer'larla çalışmıyor. Bu da elbette çalışma alanımızı daraltıyor.

Freelance gazeteciler nadiren haber hikâyelerini ya da içeriklerini seçebilme şansına sahip olabilmektedir, ancak, yine de onlar kendilerini seçim yapma hususunda daha özgür hissetmektedir. Bazı katılımcılar da haber hikâyelerini ya da içeriklerini seçebilme noktasında tam anlamıyla özgür olmadıklarını ve bunun nedenlerini şu sözlerle ifade etmiştir:

Freelance Gazeteci (15): Kendim seçiyorum ve kısıtlanmadığım için özgürüm diyebilirim.

Freelance Gazeteci (11): Kimi zaman birlikte çalıştığım editörler ilgi alanım dâhilinde benden haberler isteyebiliyor, ama çoğu zaman yazmak istediğim 
şeyleri ben öneriyorum. Bu da elbette bir özgürlük hissi getiriyor, çünkü gerçekten önemli bulduğum konulara odaklanıp onların üzerinde çalışabiliyorum.

Freelance Gazeteci (9): Eğer herhangi bir ajans, gazete veya medya şirketinden bir iş almadıysak, tabii ki haber içeriğini ve hikâyeleri kendimiz seçiyoruz. Evet, bu durum tamamen bir özgürlük hali. Zaten freelancer'ların çoğu bu yüzden 'freelance gazeteci' olmayı tercih eder.

Freelance Gazeteci (16): Türkiye'de Batı ülkelerinde olduğu gibi freelance haber içeriğini belirleyip iş yapmak kolay değil. Zira ülkede hala haber üretmek için büyük medya kuruluşlarının mali katkısına ihtiyaç var. Haber üretimi maliyetli bir iş. Böyle olunca ortaya çıkardığınız ürün de pahalı. Ücret politikaları gereği yerli basın-yayın organları freelance gazeteciler ile çalışmak yerine düşük maaşlar ile bünyesinde tuttuğu kendi muhabirleri ile çalışmayı tercih ediyor. Zira bu maliyetleri aşağıya çekiyor. Freelance gazetecilerin istedikleri haberi üretip yayımlayabilmeleri ancak şimdilerde adından söz etmeye başladığımız yeni medya organları sayesinde mümkün olabilir. Bu da şimdilik pek yaygın bir durum değil. Bu sebeplerle, Türkiye'de freelance gazeteciler genellikle yabancı yayın organları için fixer/prodüktör olarak çalışıyorlar.

Freelance gazeteciler çalışma saatlerinin esnekliği ve bu esnekliğin sağladığı avantajlar konusunda hemfikirdir. Ancak, bazı katılımcılar, bu esnekliğin, işe ve güne göre değiştiğini belirtmektedir.

Freelance Gazeteci (17): Çalışma saatlerim çok esnek. Gündüz vakti ya da sabah saatleri işte masa başında olmak yerine kişisel aktivitelere vakit ayırıp gerekirse gece çalışabiliyorum. Ya da başka kişisel işlerim olduğunda ya da çalışmaktan yorgun düştüğümde kendi kararımla kendime birkaç saat ayırabiliyorum.

Freelance Gazeteci (13): Işse bağlı. işin kendisini alırken evet tamamen esnek. $O$ işi alabilirsin ya da almayabilirsin. Bunun sağladığı avantajlar ve daha verimli boş vakit. Kendini geliştirmek için bolca vaktin var. Ayrıca, mesai saatiyle çalışmanın getirdiği yıpratıcı etkilerden korunmuş oluyorsun ... Ama çalışma saatlerinin esnek olmadığı işler de vardır. Her gün belirli bir rutin içinde çalışmak zorunda kalabilirsin.

Geleneksel bir haber kuruluşunun tamgün çalışanı olmamak freelance gazeteciler için hem bir avantajdır hem de bir dezavantajdır. Freelance gazeteciler, özellikle, kurumsal baskı mekanizmaları, kurumsal engeller, liyakat ve ehliyet, editöryal bağımsızlık, boş vakit ve gelir gibi unsurlar söz konusu olduğunda geleneksel bir haber kuruluşunun tamgün çalışanı olmamanın avantajlı olduğunu ifade etmektedir. Ancak, gazeteciler; basın kartı, basın sigortası, sağlık sigortası ve emeklilik söz konusu olduğunda freelance gazeteciliğin dezavantajlı olduğunu belirtmektedir.

Freelance Gazeteci (11): ... kurumsal baskı mekanizmalarına ve engellere takılmadan işimi yapabiliyorum. Eğer yazmak istediğim bir haberi teklif ettiğim bir yer istemezse ya da 'riskli' bulursa işimi kaybetmek yerine başkalarına gidebilme şansım var. Ya da basın sektöründeki ekonomik sıkıntılar yüzünden her an gözden çıkarılabilirim korkusunu yaşamıyorum. Bunun yanı sıra, çok 
yönlü çalışan birisi olduğum için de kurumsal çalışma saatleri gibi kısıtlamalar ile uğraşmak zorunda kalmıyorum.

Freelance Gazeteci (12): Liyakat ve ehliyet anlamında sizden aşağıda kimselerle muhatap olma zorunluluğu ortadan kalkıyor.

Freelance Gazeteci (13): Daha fazla editöryal bağımsızık, daha fazla ve verimli boş vakit, uzmanlaşma konusunda fırsat, daha tatmin edici ücret.

Freelance Gazeteci (16): Kendinize daha fazla vakit ayırabiliyorsunuz. Fakat freelance gazeteci olarak çalışmak ve hep bir sonraki işi kovalamak zorunda olmak da bir stres kaynağı olabiliyor.

Freelance Gazeteci (17): Bir haber kuruluşunun tamgün çalışanı olmak da bence çok avantajlı. Mesela basın kartı , basın sigortası gibi avantajlarınız olabiliyor. Sizi koruyan ve kollayan bir haber kuruluşu olması freelance gazeteciler için çok önemli günümüz Türkiye koşullarında.

Freelance Gazeteci (10): Sağlık sigortası ve emeklilik gibi haklarım olmadığı için kendime daha çok dikkat etmemi ya da başıma gelebilecek kötü bir duruma psikolojik olarak hazırlıklı olmamı sağlıyor.

Bir freelance gazeteci olarak çalışmanın gazetecilerin daha fazla sosyalleşmesine ve çevrelerinin genişlemesine neden olduğu düşünülmektedir. Freelance gazeteciler, bu konuda farklı görüşlere sahip olmakla birlikte, daha fazla sosyalleşmenin ve geniş bir çevreye sahip olmanın avantajlarını şöyle açıklamıştır:

Freelance Gazeteci (10): Bendeniz, mümkün olduğu kadar kendi başına kalmaya çalışan bir gazeteciyim. Tabii ki, pek çok kişiyle karşılaşıyorum işim gereği. Ama sakınıyorum.

Freelance Gazeteci (16): Al Jazeera Ingilizce kanalı için freelance prodüktör olarak çalıştığım dönemde Ankara'daki resmî kurumlardan çok daha fazla haber kaynağım oldu. Zira bir kurumda düzenli olarak çalışırken o kurumun çeşitli şehirlerde temsilcileri olması nedeniyle, o alanlarla ilgili çalışma şansınız azalıyor (tabii ki tamamen ortadan kaldırmıyor, ancak, kurum içi dengeleri gözetmek zorunda olmak vs. elinizi bağlayabiliyor). Fakat freelance çalışmak bu anlamda sizi rahatlatıyor. Haber çevreniz genişliyor. Ancak, bunun göreceli bir durum olduğunu da kaydetmek gerekir.

Freelance Gazeteci (17): ... farklı kurumlarla çalıştıkça hem yeni insanlarla tanışıp iş çevremi genişletiyorum hem de farklı hikâyeler öğrenip onlar üzerine okuma şansı elde edebiliyorum, kesinlikle çok büyük avantajları var.

Freelance gazetecilerin bazıları hem çalışma hem de yaşam koşullarından memnundur, bazıları da hem çalışma hem de yaşam koşullarından memnun değildir. Gazeteciler memnuniyet(sizlik)lerinin nedenlerini şöyle açıklamıştır:

Freelance Gazeteci (5): Maddi olarak maalesef memnun değilim. Fakat gazetecilik mesleği zaten maddi olarak tatmin olacağını bir iş hiçbir zaman olmadı, bir kurumda çalışsanız bile.

Freelance Gazeteci (6): ... tam zamanlı bir yerde çalışırken maaş ve mesai sorunları oluyordu. Şimdi ise gazeteciliği bir meslek değil, yaşam biçimi olarak

42015 yılında, freelance gazeteciler, Türkiye Gazeteciler Sendikası'nın (TGS) vermeye yetkili olduğu Uluslararası Basın Kartı'nı almaya başlamışıı. Sendika ve Uluslararası Gazeteciler Federasyonu (IFJ) arasındaki protokol gereği, 134 ülkede geçerli olan Uluslararası Basın Kartı'na sahip olabilmek için freelance gazetecilerin, yaptıkları haberler ve çektikleri görüntülerle sendikaya başvurması istenmiştir (TGS, 2015). 
tanımlıyorum. Bu nedenle, haberlerimi ve dosya konularımı daha bir hevesle hazırlıyorum. Bıkkınlık kesinlikle yaşamıyorum. Ancak, bunda, birincil ekonomik kaynağımın gazetecilik olmamasının da büyük etkisi var.

Freelance Gazeteci (9): Memnunum çünkü özgürüm.

Freelance Gazeteci (13): Memnun olduğumu söyleyebilirim. Ben çok fazla iş almıyorum, bu kısmen bir tercih. Artık Istanbul'da yaşamıyorum ve kendimi bu anlamda kurtulmuş hissediyorum. Orada olsam daha çok iş alma şansım olurdu, ama bu beni kişisel anlamda tatmin etmeyeceği gibi daha çok yıpratır ve mutsuz ederdi. Şu anki yaşam koşullarım beni tatmin ediyor ve bunu da freelance gazetecilik sağlıyor. Dediğim gibi ideal olan bu değil, ama bir alternatif olarak da kötü sayılmaz.

Freelance Gazeteci (16): Bazen uzun ve yorucu bir çalışma temposu söz konusu olabiliyor. Freelance olduğunuz için çalıştığınız kurumlar sizden mümkün olduğu kadar çok faydalanmak istiyor. Dolayısıyla, kimi zaman bu ağır çalışma koşulları sizi zorluyor, memnuniyetinizi aşağıya çekiyor. Bu da çok daha fazla yorgunluğa neden olabiliyor.

Freelance Gazeteci (17): Evet, memnunum. Çünkü vaktimi kendim yönetebildiğim sürece çalışma saatlerimi kendim belirliyorum, çalışmak istediğim kurumları kendim belirliyorum ve bu da bana iş hayatında mutluluk veriyor. Ayrıca, entelektüel açıdan da istediğim kişilerle, istediğim işlerde çalışma firsatım oluyor.

Türkiye'de bir freelance gazeteci olarak çalışırken erkek ya da kadın olmanın (dez)avantajlarını ise katıımcılar şu ifadelerle dile getirmektedir:

Freelance Gazeteci (9): Ülkemiz maalesef halen kadın ve erkek eşitliğini kabullenebilmiş değil. Bu doğrultuda erkekler bu mesleği daha rahat yapıyor. Bu acı bir gerçek. Bazen bir haberin peşindeyken, haber kaynağı sizin yerinize sadece erkek olduğu için rakibinizi tercih ederse şaşırmayın. Bunlar sık yaşanıyor.

Freelance Gazeteci (12): Freelance çalışan erkekler çevre yapar ve kurumsal pozisyonlara atlarlar, kadın gazeteciler yazık ki o 'gezme, maça gitme, yeme içme' halkasının içine girmez ve doğal olarak kariyerleri yarım ve başarısız kalır. Bu bütün sektörler için geçerlidir ve son dönemde daha artan bir vahşilikte devam etmektedir.

Freelance Gazeteci (16): Bir erkek gazeteci olarak rahatıkla söyleyebilirim ki, tüm çalışma ortamlarında kadın gazeteci olmak daima daha zor. Hele de alanda çalışıyorsa bu zorluklar ikiye katlanabilir. Fakat mesleki deneyimim, kadınların bütün işlerde erkekler kadar, hatta daha fazla başarı kazandıklarıdır. Ancak, toplumsal cinsiyet eşitsizliği nedeniyle gerek ücretler, gerekse sağlanan imkânlar açısından bakıldığında kadın gazeteciler zorluklar yaşıyor.

\section{Sorunlar}

Türkiye'de freelance gazeteciliğe ilişkin hukuki bir düzenlemenin henüz yapılmamış olması ve bu bağlamda, freelance gazeteciliğin yasal olarak tanımlanamaması büyük bir sorundur. Aynı sorun, freelance gazetecilerin yasal statülerinin belirsizliği söz konusu olduğunda da gündeme gelmektedir. Kavramsal olarak freelance gazeteciliğin çok az biliniyor olması da, basın toplantıları ve akreditasyon söz konusu olduğunda freelance gazetecilerin sıkıntı yaşamalarına neden olmaktadır. Sendikal haklardan yararlanamayan ve buna bağlı olarak iş ve gelir güvence- 
sinden yoksun olan freelance gazeteciler, düzenli bir gelir elde edememekte ve zaman zaman sigortasız çalışmak zorunda bırakılmaktadır. SGK (Sosyal Güvenlik Kurumu) primlerinin yatııımaması ve sağlık harcamalarının ancak özel sigorta sistemi ile karşılanıyor olması da gazetecileri zor durumda bırakmaktadır.

Freelance Gazeteci (13): Yasal olarak net bir tanımının olmaması ve geçici bir statü gibi algılanması; bununla bağlantılı olarak, sosyal güvencemizin olmaması, 212'den yararlanamamak; toplumun genel zihin yapısında karşılık bulmaması, bu, haber kaynaklarımızın ya da röportaj yapacağımız insanların algısını da şekillendiren ciddi bir sorun; çoğu zaman haberlerde isimlerimizin yer almaması.

Freelance Gazeteci (7): Her şeyden önce Türkiye'de freelance gazetecilik diye bir kavramı çok az kişi biliyor. Bir basın toplantısında ve organizasyonların akreditasyonlarında da bundan kaynaklı problemler yaşanıyor. Freelance çalıştığınız için sizinle ilişkilendirilmiş bir kurumu muhatap alamadıkları için çoğu zaman haber kaynakları vb. kişiler güvensizlik hissediyorlar freelance gazetecilere karşı.

Freelance Gazeteci (10): Türkiye'de freelance gazetecilik bilinmez. Freelance gazeteci, gazeteci kabul edilmez. Bu, sahada büyük güvenlik sorunlarına neden olur. Haber ve kaynağına ulaşabilmek için de büyük handikaplara yol açar.

Freelance Gazeteci (11): Güvencesizlik. Yaptığımız mesleğin getirmesi gereken hiçbir güvenceden faydalanamıyoruz. Sendikalaşma hakkımız bile yok, çünkü bir kurumda çalışmadığımı için teknik olarak gazeteci sayılmıyoruz ve bu yüzden de sendika üyesi olamıyoruz. Bu da bizim birçok anlamda daha fazla ezilmemize ve haklarımızın çiğnenmesine neden oluyor.

Ödemelerimizi almakta ciddi sıkıntılar yaşıyoruz. Birçok kurum freelance gazetecilere ya ücretsiz gazeteci ya da en son elde para kalırsa ödemesi yapılacak kişi gözüyle bakıyor. Bunu da bahsettiğim güvencesiz olma durumumuzu kullandıkları için daha rahat bir şekilde yapabiliyorlar.

işimiz tanınmıyor. Hali hazırda gazetecilerin ülkemizde kendilerini kabul ettirme sorunu yaşadığını biliyoruz. Birçok insanın sırf yazdıkları beğenilmediği için gazeteciliği sorgulanıyor. Neredeyse devlet tarafından verilen basın kartı sahipleri dışında kimsenin gazeteci kabul edilmediği bir noktada, bizim gibi bir kuruma bağlı olmadan çalışanları neredeyse kimse gazeteci olarak görmüyor.

Türkiye'de freelance gazetecilerin, freelance gazetecilik yaparken karşılaştıkları sorunlar bir katılımcı tarafından şöyle açıklanmıştır:

Freelance Gazeteci (16): Eğer sürekli basın kartı sahibi değilseniz, her defasında devletin ilgili kurumuna başvurarak geçici süreli basın kartı almak gibi bir prosedürel sıkıntı var. Alanda çalışırken basın kartınız yoksa ciddi sorunlar ile karşılaşabilirsiniz. Freelance gazetecinin gazeteci kabul edilmesi, sarı basın kartı taşıması için gazeteci örgütlerinin de devreye girmesi gerekirdi. Fakat sanıyorum içinden geçtiğimiz siyasal süreçte bunun için geç kalmış durumdayız. Bir kurum için değil, parça başı kendiniz için haber üretecekseniz kendinizi haber kaynağına anlatmak çok zordur. Genellikle haber kaynakları, 'güvenilirlik' açısından kurumlara freelance gazetecinin şahsından daha fazla itibar ediyor. Freelance çalışmak örgütlü çalışmaya engeldir. Karşılaşacağınız çeşitli zorluklarda arkanızda duracak bir kurumun olmaması sıkıntıyı daha da artırıyor.

Freelance gazetecilerin haklarını koruyabilmeleri için meslek örgütlerinin 
bu gazetecileri tanıması ve onlarla dayanışma içinde olması gerekmektedir. Ayrıca, pahalı bir iş olan iyi gazetecilik için ulusal ve uluslararası fonlar oluşturulabilmeli ve belirli özelliklere sahip bağımsız gazeteciler bu fonlardan yararlanabilmelidir. Çünkü daha deneyimli işsiz gazetecilerin önündeki en büyük engellerden biri, gazeteciliğin maliyetidir.

Freelance Gazeteci (4): Meslek haklarını koruyan bir düzenlemenin ve kuruluşun olmaması.

Freelance Gazeteci (6): Batı ülkelerindeki gazetecilerin aksine Türkiye'de freelance'lik bir sözleşmeye dayanmıyor. Meslek örgütleri de bu konuda çok yetersiz. Yasal bir belirsizlik var. Sizi gazeteci olarak görmüyorlar. Gazeteci olmanın özel haklarından ve mesleki kurslardan yararlanamıyorsunuz. Sürekli bağımsızlığın iyi tarafından bahsediyoruz ama gazeteciliği finanse edecek esnek ikinci işiniz yoksa gazetecilik yapacak gücünüzde kalmıyor. Bunlar hep yaşamsal sorunlar.

\section{Sonuç ve Öneriler}

Freelance gazetecilerin mesleki haklarının korunması, iş ve gelir güvencesinden yoksun kalma riskinin ortadan kaldıııması ve çalışma koşullarının iyileştirilmesi için öncelikle devletin girişimde bulunması ve freelance gazetecilik yapan gazetecilere yardımcı olması gerekmektedir. Örneğin, Basın-Yayın ve Enformasyon Genel Müdürlüğü'nün (BYEGM) (görev ve yetkileri Türkiye Cumhuriyeti Cumhurbaşkanlığı İletişim Başkanlığı'na devredilmiştir) diğer gazetecilere sağladığı tüm haklardan ve imkânlardan freelance gazetecilerin de faydalanabilmesi için harekete geçilmelidir. Sigorta ve emeklilik gibi konularda iyileştirmeler yapılmalı ve eğer mümkünse, bir başka alternatif olarak devlet katkıları artııımalıdır. Meslek örgütlerinin freelance gazetecileri tanıması ve onlarla dayanışma içinde olması son derece önemlidir. Özellikle yalnızca freelance gazeteciler için bir meslek birliğinin kurulması, sözü edilen sorunların ortadan kaldırıması için büyük bir önem taşımaktadır.

Freelance gazeteciliğin ve gazetecilerin önündeki en büyük engel, sendikalaşamamaktır. Sendikal haklara sahip olmayan freelance gazeteciler, sömürülebilmekte ve iş yaptıkları kişilere ya da kurumlara karşı savunmasız bir pozisyonda, kendilerini koruyamamakta ve emeklerinin karşı̆̆ını tam olarak alamamaktadır. Bu noktada, freelance gazetecilere karşı yaklaşımın tamamen değişmesi gerekmektedir. Her şeyden önce, freelance gazetecilerin yakındıkları en temel sorunlardan biri, onlara 'gerçek' gazeteci gözüyle bakılmaması ve ciddiye alınmamalarıdır. Bu temel sorunun çözümlenebilmesi için gazetecilerin öncelikle genel olarak iş ve gelir güvencesine sahip olması ve freelance gazetecilik mesleğinin toplumsal saygınlığa kavuşturulması gerekmektedir. Yine freelance gazetecilerin ifadesiyle, kimin gazeteci olup olamayacağına devlet değil, gazetecilerin kendi kurumları karar verebilmeli ve basın kartı daha özgür bir kurumdan alınabilmelidir. Zaman zaman bir medya kuruluşu ile sigortalı bir sözleşme yapmamış oldukları için freelance gazeteciler, gazeteci olduklarını kanıtlayamamaktadır. Bu nedenle, mesleki faaliyetlerini daha rahat gerçekleştirebilmeleri için freelance gazetecilerin rahatlıkla basın kartı alabilmesi gerekmektedir. 
Meslek örgütleri tarafından freelance gazeteciliğin ve gazetecilerin yasal tanımının yapılması şarttır. Freelance gazeteci kendisinin gazeteci olduğunu kanıtlayacak bir kimliğe sahip olmadığı sürece toplumsal karşılığı da olmayacaktır. Yeni medya da freelance gazetecilik ve gazeteciler söz konusu olduğunda, hukuki boşlukları gündeme getirmektedir. Bu bağlamda, yeniden ortak akıl aracılığıyla ortaya çıkan hukuki boşluklar belirlenmeli, freelance gazeteciliğin de dâhil olduğu gazetecilik alanları yeniden tanımlanmalı ve hukuki eksiklikler ortadan kaldırımalıdır. Bütün bu yasal, siyasal ve ekonomik düzenlemelerin ötesinde, freelance gazetecilerin çalışma koşullarının çok daha derinlemesine araştıııması büyük önem taşımaktadır. Daha önce diğer ülkelerde yapılmış araştırmalarda, freelance çalışma pratiğinin, freelance medya işçileri üzerindeki olumsuz sosyo-psikolojik etkilerini gözler önüne seren ve aynı zamanda, bu pratiğin gazetecilerin yaşadıkları stresi artırdığını ve dolayısıyla, sağlık sorunları yaşamalarına neden olduğunu gösteren bulgular ortaya konulmuştur (Hesmondhalgh ve Baker, 2011; Ertel vd., 2005). Aynı şekilde, Türkiye'de, alanyazındaki büyük bir boşluğu dolduracak olan benzer araştırmaların, yalnızca gazetecilere değil, freelance çalışan tüm medya mensuplarına odaklanması gerekmektedir.

\section{Kaynakça}

Aitamurto, T. (2015). The Role of Crowdfunding as a Business Model in Journalism: A Five-Layered Model of Value Creation. L. Bennett, B. Chin ve B. Jones (Ed.), Crowdfunding the Future: Media Industries, Ethics and Digital Society içinde (189-205). New York: Peter Lang.

Aitamurto, T. (2011). The Impact of Crowdfunding on Journalism: Case Study of Spot.Us, a Platform for Community-Funded Reporting. Journalism Practice, 5(4), 429-445.

Andersson, U. ve Wiik, J. (2013). Journalism Meets Management: Changing Leadership in Swedish News Organizations. Journalism Practice, 7(6), 705-719.

Baines, D. ve Kennedy, C. (2010). An Education for Independence: Should Entrepreneurial Skills be an Essential Part of the Journalist's Toolbox?. Journalism Practice, 4(1), 97-113.

Carvajal, M., García-Avilés, J. A. ve González, J. L. (2012). Crowdfunding and Non-Profit Media: The Emergence of New Models for Public Interest Journalism. Journalism Practice, 6(5-6), 638-647.

Cohen, N. S. (2016). Writers' Rights: Freelance Journalism in a Digital Age. Montreal, Kingston: Mcgill Queen's University Press.

Cohen, N. S. (2015a). From Pink Slips to Pink Slime: Transforming Media Labor in a Digital Age. The Communication Review, 18(2), 98-122.

Cohen, N. S. (2015b). Entrepreneurial Journalism and the Precarious State of Media Work. South Atlantic Quarterly, 114(3), 513-533.

De Cock, R. ve de Smaele, H. (2016). Freelancing in Flemish News Media and 
Entrepreneurial Skills as Pivotal Elements in Job Satisfaction. Journalism Practice, 10(2), 251-265.

Das, J. (2007). Sydney Freelance Journalists and the Notion of Professionalism. Pacific Journalism Review, 13(1), 142-160.

Edström, M. ve Ladendorf, M. (2012). Freelance Journalists as a Flexible Workforce in Media Industries. Journalism Practice, 6(5-6), 711-721.

Elmore, C. ve Massey, B. (2012). Need for Instruction in Entrepreneurial Journalism: Perspective of Full-Time Freelancers. Journal of Media Practice, 13(2), 109-124.

Ertel, M., Pech, E., Ullsperger, P, Knesebeck, O. ve Siegrist, J. (2005). Adverse Psychosocial Working Conditions and Subjective Health in Freelance Media Workers. Work\&Stress: An International Journal of Work, Health\&Organisations, 19(3), 293-299.

Fröhlich, R., Koch, T. ve Obermaier, M. (2013). What's the Harm in Moonlighting? A Qualitative Survey on the Role Conflicts of Freelance Journalists with Secondary Employment in the Field of PR. Media, Culture\&Society, 35(7), 809-829.

Gollmitzer, M. (2014). Precariously Employed Watchdogs? Perceptions of Working Conditions among Freelancers and Interns. Journalism Practice, 8(6), 826841.

Gynnild, A. (2005). Winner Takes It All: Freelance Journalism on the Golobal Communication Market. Nordicom Review, 26(1), 111-120.

Hesmondhalgh, D. ve Baker, S. (2011). Creative Labour: Media Work in Three Cultural Industries. London: Routledge.

Holton, A. E. (2016). Intrapreneurial Informants: An Emergent Role of Freelance Journalists. Journalism Practice, 10(7), 917-927.

Hunter, A. (2016). It's Like Having a Second Full-Time Job: Crowdfunding, Journalism and Labour. Journalism Practice, 10(2), 217-232.

Hunter, A. (2015). Crowdfunding Independent and Freelance Journalism: Negotiating Journalistic Norms of Autonomy and Objectivity. New Media\&Society, 17(2), 272-288.

Jian, L. ve Shin, J. (2015). Motivations Behind Donors' Contributions to Crowdfunded Journalism. Mass Communication and Society, 18(2), 165-185.

Jian, L. ve Usher, N. (2014). Crowd-Funded Journalism. Journal of Computer-Mediated Communication, 19(2), 155-170.

Johnson, J. M. ve Rowlands, T. (2012). The Interpersonal Dynamics of In-depth Interviewing. J. F. Gubrium, J. Holstein, A. Marvasti ve K. McKinney (Ed.), The Sage Handbook of Interview Research içinde (99-113). Los Angeles: Sage.

Kaye, J. ve Quinn, S. (2010). Funding Journalism in the Digital Age: Business 
Models, Strategies, Issues and Trends. New York: Peter Lang.

Ladendorf, M. (2012). Freelance Journalists' Ethical Boundary Settings in Information Work. Nordicom Review, 33(1), 83-98.

Massey, B. ve Elmore, C. (2011). Happier Working for Themselves? Job Satisfaction and Women Freelance Journalists. Journalism Practice, 5(6), 672-686.

Mathisen, B. R. (2017). Entrepreneurs and Idealists: Freelance Journalists at the Intersection of Autonomy and Constraints. Journalism Practice, 11 (7), 909-924.

McChesney, R. W. ve Pickard, V. (2011). Will The Last Reporter Please Turn Out The Lights? The Collapse of Journalism and What Can Be Done To Fix It. New York: The New Press.

McChesney, R. W. ve Nichols, J. (2010). The Death and Life of American Journalism: The Media Revolution That Will Begin the World Again. Philadelphia: Nation Books.

Obermaier, M. ve Koch, T. (2015). Mind the Gap: Consequences of Inter-Role Conflicts of Freelance Journalists with Secondary Employment in the Field of Public Relations. Journalism, 16(5), 615-629.

Porlezza, C. ve Splendore, S. (2016). Accountability and Transparency of Entrepreneurial Journalism. Journalism Practice, 10(2), 196-216.

Ryan, K. M. (2009). The Performative Journalist: Job Satisfaction, Temporary Workers and American Television News. Journalism, 10(5), 647-664.

Smith, V. (2011). Freelance Journalism. J. Owen ve H. Purdey (Ed.), International News Reporting: Frontlines and Deadlines içinde (55-70). USA, UK: Wiley-Blackwell.

Solomon, E. F. (2016). How Freelance Journalists Can Help Shape Journalism Education. Journalism and Mass Communication Educator, 71(2), 241-247.

Standing, G. (2011). The Precariat: The New Dangerous Class. London: Bloomsbury Academic.

Türkiye Gazeteciler Sendikası (2015). Freelance Çalışanlara Basın Kartı Kolaylığı. Erişim: 29 Nisan 2018, https://tgs.org.tr/freelance-calisanlara-uluslararasi-basin-karti-kolayligi

Wahl-Jorgensen, K. ve Hanitzsch, T. (2009). Introduction: On Why and How We Should Do Journalism Studies. K. Wahl-Jorgensen ve T. Hanitzsch (Ed.), The Handbook of Journalism Studies içinde (3-16). New York: Routledge.

Walters, E., Warren, C. ve Dobbie, M. (2006). The Changing Nature of Work. A Global Survey and Case Study of Atypical Work in the Media Industry. International Federation of Journalists. 